\title{
Preventive effects of Dendrobium candidum Wall ex Lindl. on the formation of lung metastases in BALB/c mice injected with 26-M3.1 colon carcinoma cells
}

\author{
GUIJIE LI ${ }^{1,2^{*}}$, PENG SUN $^{1 *}$, YALIN ZHOU ${ }^{1}, \mathrm{XIN} \mathrm{ZHAO}^{1}$ and FENG CHEN ${ }^{2}$ \\ ${ }^{1}$ Department of Biological and Chemical Engineering, Chongqing University of Education, Chongqing 400067, P.R. China; \\ ${ }^{2}$ Department of Food, Nutrition and Packaging Science, Clemson University, Clemson, SC 29634, USA
}

Received January 25, 2014; Accepted July 8, 2014

DOI: $10.3892 / 01.2014 .2383$

\begin{abstract}
Dendrobium candidum Wall ex Lindl. (D. candidum) is a traditional Chinese medicine widely used in Asia. The present study has showed that D. candidum exerted an anti-metastatic effect in mice injected with 26-M3.1 colon carcinoma cells. D. candidum showed the most marked tumor inhibitory rate of $64.5 \%$ at a dose of $400 \mathrm{mg} / \mathrm{kg}$ body weight (b.w). The mRNA and protein expression of Bax in lung tissue of $D$. candidum-treated mice was shown to be higher as compared with control mice, whereas the mRNA and protein expression of Bcl-2 showed the opposite trend. Decreased mRNA and protein expression of MMP and increased expression of TIMPs was demonstrated in lung tissues by quantitative polymerase chain reaction and western blot assays. D. candidum reduced the serum cytokine levels of IL-6, IL-12, TNF- $\alpha$ and IFN- $\gamma$ to a greater extent as compared with the control mice, and administration of $400 \mathrm{mg} / \mathrm{kg}$ b.w. resulted in a lower serum cytokine levels as compared with mice treated with $200 \mathrm{mg} / \mathrm{kg}$ b.w. Eleven compounds were in the $D$. candidum leaf, of which the functional contents may help to generate novel treatments for the prevention of lung metastases. The results of the present study have demonstrated that $D$. candidum had a potent in vivo antitumor and anti-metastatic effect in $\mathrm{BALB} / \mathrm{c}$ mice injected with 26-M3.1 cells.
\end{abstract}

Correspondence to: Professor Xin Zhao, Department of Biological and Chemical Engineering, Chongqing University of Education, 9 Xuefu Main Street, Nan'an District, Chongqing 400067, P.R. China E-mail: foods@live.cn

Professor Feng Chen, Department of Food, Nutrition and Packaging Science, Clemson University, 223 Pool Ag Center, P.O. Box 340316, Clemson, SC 29634, USA

E-mail: fchen@clemson.edu

${ }^{*}$ Contributed equally

Key words: Dendrobium candidum, cytokine, anticancer, apoptosis, anti-metastasis

\section{Introduction}

Dendrobium is a large genus of orchids, and Dendrobium candidum Wall. ex Lindl. (D.candidum) is a functional analog of Dendrobium moniliforme (L.) Sw. $(1,2)$. It is a traditional Chinese medicinal herb that is used either raw or processed for healthcare products in China (3). D. candidum contains water-soluble polysaccharides, phenanthrenes and numerous amino acids. High contents of chrysotoxen and erianin may have inhibitory activities in liver cancer and ehrlich ascites carcinoma cells (4).

Metastasis is defined as the spread of cancer cells from one organ or area to another adjacent organ or location (5) and it is considered that malignant tumor cells have the capacity to metastasize. Cancer can occur in cells of a tissue that are genetically mutated in a progressive manner, resulting in cancer stem cells possessing a malignant phenotype (6). Metastasis is the leading cause of mortality among cancer patients, and involves the spread of cancer from a primary site and formation of new tumors in distant organs (7). Matrix metalloproteinases (MMPs) function in numerous physiological and pathological processes, including embryonic development, morphogenesis, reproduction, tissue remodeling, arthritis, cardiovascular disease and metastasis (8). MMP activity is inhibited by specific endogenous tissue inhibitors of metalloproteinases (TIMPs) (9). To prevent the majority of cancer types, improved treatments against metastasis are needed (10).

D. candidum has been previously shown to exhibit strong in vitro anticancer effects on HeLa S3 human cervical carcinoma cells and HepG2 liver cancer cells (9). In the present study, the anti-metastatic effects of $D$. candidum were investigated in mice injected with 26-M3.1 colon carcinoma cells, and the molecular mechanisms underlying the anti-metastatic effects of the D. candidum were studied. The in vivo anti-metastatic effects were determined by tumor count, cytokine levels, and mRNA and protein expression experiments. The association between the anticancer activities and functional components of $D$. candidum was additionally explored.

\section{Materials and methods}

Preparations of D. candidum. D. candidum was purchased from Shanghai Pharmacy Co., Ltd. (Shanghai, China). The 
D. candidum was stored at $-80^{\circ} \mathrm{C}$ and freeze-dried to produce a powder. A 20 -fold volume of boiling water was added to the powdered sample and extracted twice by stirring overnight. The aqueous extract was evaporated and concentrated using a rotary evaporator (N-1100; Eyela, Tokyo, Japan).

Anti-metastatic effects of $D$. candidum in mice bearing 26 M3.1 cells. The following experiment was performed according to the methods of a previous study (11). 26-M3.1 colon carcinoma cells were obtained from Professor Yoon (Department of Food and Nutrition, Yuhan University, Bucheon, South Korea). The metastatic cells were cultured in Eagle's minimum essential medium (Gibco-BRL, Carlsbad, CA, USA) supplemented with 7.5\% FBS (fetal bovine serum), a vitamin solution, sodium pyruvate, non-essential amino acids and L-glutamine (Gibco-BRL) by $5 \% \mathrm{CO}_{2}$ at $37^{\circ} \mathrm{C}$. The 6-week-old female Balb/c mice (Experimental Animal Center of Chongqing Medical University, Chongqing, China) were induced lung metastasis by injecting colon 26-M3.1 cells. The experimental mice were divided three groups, there were 20 mice in each group. The control group of mice was without any treatment for 2 weeks. The $D$. candidum group mice were treated with $D$. candidum aqueous extract solutions (200 and $400 \mathrm{mg} / \mathrm{kg}$ b.w.) by gavage for 2 weeks. After 2 weeks, all the mice were intravenously inoculated with 26-M3.1 cells at the concentration of $2.5 \times 10^{4} /$ mouse. Two days later, the mice were sacrificed and the lungs of 10 mice in each group were fixed in Bouin's solution (saturated picric acid: formalin: acetic acid; 15:5:1, v/v/v) (12). Then the rates of metastasis were determined by counting tumor colonies in the photos (Canon D550; Canon, Tokyo, Japan). Inhibitory rate $=$ [(lung tumor number of control mice - lung tumor number of $\mathrm{D}$. candidum treated mice)/lung tumor number of control mice] x 100\%. The other lungs of 10 mice in each group were tested for reverse transcription (RT)-PCR and western blot assays. The protocol for these experiments was approved by the Animal Ethics Committee of Chongqing Medical University.

Analysis of IL-6,IL-12, TNF- $\alpha$ and IFN- $\gamma$ cytokines in serum by ELISA. For the serum cytokine assay, blood from the inferior vena cava was collected in a tube and centrifuged at $1100 \mathrm{x} \mathrm{g}$ and $4^{\circ} \mathrm{C}$ for $10 \mathrm{~min}$. The serum was aspirated and assayed as described below. Concentrations of cytokines of IL-6, IL-12, TNF- $\alpha$ and IFN- $\gamma$ in serum were measured using mouse IL-6, IL-12, TNF- $\alpha$ and IFN- $\gamma$ ELISA kits according to the manufacturer's instructions (Biolegend, San Diego, CA, USA). Briefly, biotinylated antibody reagent was added to 96-well plates, then supernatants of homogenized serum were added and the plates were incubated at $37^{\circ} \mathrm{C}$ in $\mathrm{CO}_{2}$ for $2 \mathrm{~h}$. After washing with phosphate-buffered saline (PBS), streptavidin-horseradish peroxidase (HRP) solution was added and the plate was incubated for $30 \mathrm{~min}$ at room temperature. The absorbance was measured at $450 \mathrm{~nm}$ using a microplate reader (iMark; Bio-Rad, Hercules, CA, USA) (13).

$R T$-PCR. RT-PCR was performed according to the methods descirbed in a previous study (11). The RNA of lung tissue was treated with TRIzol reagent (Invitrogen Life Technologies, Carlsbad, CA, USA) for extraction. After total RNA was digested with RNase-free DNase (Roche, Diagnostics Basel,
Switzerland) for $15 \mathrm{~min}$ at $37^{\circ} \mathrm{C}$, then the digested RNA was purified by RNeasy kit (Qiagen, Hilden, Germany). The cDNA was synthesized from $2 \mu \mathrm{g}$ of total RNA at $37^{\circ} \mathrm{C}$ for $1 \mathrm{~h}$ with AMV reverse transcriptase (GE Healthcare, Little Chalfont, Buckinghamshire, UK) (2). Sequences of Bax, Bcl-2, MMPs and TIMPs were specifically amplified (Table I) by thermal cycler (Eppendorf, Hamburg, Germany). The PCR products were separated in $1.0 \%$ agarose gels and visualized with ethidium bromide staining.

Protein extraction and western blot analysis in the gastric tissue. Total lung tissue protein was obtained with radioimmunoprecipitation assay buffer as described (12). Protein concentrations were determined with a Bio-Rad protein assay kit (Bio-Rad, Hercules, CA, USA). For the western blot analysis, aliquots of the lysate containing 30-50 $\mu \mathrm{g}$ protein were separated by SDS-PAGE and then electrotransferred onto a nitrocellulose membrane (Schleicher and Schuell, Keene, NH, USA). The membranes were subjected to immunoblot analysis and the proteins were visualized by an enhanced chemiluminescence (ECL) method (Amersham ECL GST Western Blotting Detection kit, product code: RPN1237; GE Healthcare) then transferred onto a polyvinylidene fluoride membrane (GE Healthcare), prior to blocking with 5\% non-fat milk and hybridization with primary antibodies (diluted 1:1,000). The antibodies against Bax, Bcl-2, MMPs and TIMPs were obtained from Santa Cruz Biotechnology, Inc. (Santa Cruz, CA, USA). The membranes were then incubated with a horseradish peroxidase-conjugated secondary antibody (Santa Cruz Biotechnology, Inc.) for $1 \mathrm{~h}$ at room temperature. The blots were washed three times with PBS-Tween and then developed by ECL using GE Healthcare ECL prime western blotting detection reagent (GE Healthcare).

Component analysis by nuclear magnetic resonance (NMR). Dried D. candidum was refluxed and extracted three times with 10 times amount of ethyl acetate. The ethyl acetate extract was obtained after $1 \mathrm{~h}$ for every reflux extraction and decompression concentrating extraction. The total ethyl acetate extract was extracted by anhydrous ethanol three times. The ethanol extract thus produced was resuspended in water before extraction by petroleum ether, chloroform and butanol, respectively, as follows. Firstly, the ethyl acetate extract was treated by gradient elution in a silica gel column with a petroleum ether-ethyl acetate system. Secondly, the chloroform extract was treated by gradient elution in a silica gel column with a petroleum chloroform-methanol system. Finally, the butanol extract was agitated by water ultrasonic, filtered and then eluted by an HP2MGL macroporous resin column with water, $10 \%$ ethanol, $30 \%$ ethanol and $60 \%$ ethanol, respectively. Following elution, the different solvents had eluted various compounds, and their composition could be identified by NMR (Varian INOVO 400; Varian Inc., Palo Alto, CA, USA). The NMR was set at an ${ }^{1} \mathrm{H}$ frequency of $300 \mathrm{MHz}$, temperature of $25^{\circ} \mathrm{C}$, pulse length of $8 \mu \mathrm{sec}$ and spin speed of $20 \mathrm{~Hz}$, and scanned 64 times. The ${ }^{1} \mathrm{H}-\mathrm{NMR}$ spectra were recorded using a standard high-resolution magicangle spinning probe with magic-angle gradient.

Statistical analysis. Data are presented as the means \pm standard deviation. Differences between the mean values for individual 
Table I. Primer sequences used for quantitative polymerase chain reaction.

\begin{tabular}{ll}
\hline Gene name & Sequence \\
\hline Bax & \\
Forward & 5'-AAGCTGAGCGAGTGTCTCCGGCG-3' \\
Reverse & 5'-CAGATGCCGGTTCAGGTACTCAGTC-3' \\
Bcl-2 & \\
Forward & 5'-CTCGTCGCTACCGTCGTGACTTGG-3' \\
Reverse & 5'-CAGATGCCGGTTCAGGTACTCAGTC-3' \\
MMP-2 & \\
Forward & 5'-CTTCTTCAAGGACCGGTTCA-3' \\
Reverse & 5'-GCTGGCTGAGTACCAGTA-3' \\
MMP-9 & \\
Forward & 5'-TGGGCTACGTGACCTATGAC-3' \\
Reverse & 5'-GCCCAGCCCACCTCCACTCC-3' \\
TIMP-1 & \\
Forward & 5'-GTCAGTGAGAAGCAAGTCGA-3' \\
Reverse & 5'-ATGTTCTTCTCTGTGACCCA-3' \\
TIMP-2 & \\
Forward & 5'-TGGGGACACCAGAAGTCAAC-3' \\
Reverse & 5'-TTTTCAGAGCCTTGGAGGAG-3' \\
GAPDH & \\
Forward & 5'-CGGAGTCAACGGATTTGGTC-3' \\
Reverse & 5'-AGCCTTCTCCATGGTCGTGA-3' \\
\hline
\end{tabular}

groups were assessed by one-way analysis of variance with Duncan's multiple range test. $\mathrm{P}<0.05$ was considered to indicate a statistically significant difference. SAS, version 9.1 (SAS Institute, Inc., Cary, NC, USA) was used for statistical analyses.

\section{Results}

In vivo anti-metastatic effects of $D$. candidum. 26-M3.1 colon carcinoma cells were used to evaluate the anti-metastatic effects of D. candidum in vivo. Prophylactic inhibition of tumor metastasis by $D$. candidum was evaluated by using an experimental mouse metastasis model (Fig. 1). D. candidum-treated mice had significantly fewer lung metastatic colonies as compared with control mice (number of metastatic tumors, 62 \pm 6 ; $\mathrm{P}<0.05$ ). A dose of $400 \mathrm{mg} / \mathrm{kg}$ b.w. D. candidum was the most effective at inhibiting lung metastasis. This concentration (inhibitory rate, $64.5 \%$; number of metastatic tumors, 22 \pm 3 ) inhibited tumor formation and lung metastasis to a greater degree as compared with a dose of $200 \mathrm{mg} / \mathrm{kg}$ solution (inhibitory rate, $46.8 \%$; number of metastatic tumors, $33 \pm 4$ ).

$I L-6, I L-12, T N F-\alpha$ and IFN- $\gamma$ serum levels in mice. The control mice showed the highest serum levels of IL-6, IL-12, TNF- $\alpha$ and IFN- $\gamma$. These levels were significantly decreased in D. candidum-treated mice $(\mathrm{P}<0.05$, Table II). A higher concentration of $400 \mathrm{mg} / \mathrm{kg}$ b.w. D. candidum was more effective as compared with the $200 \mathrm{mg} / \mathrm{kg}$ b.w. dose in promoting a decrease in cytokine serum levels.
Apoptosis-related gene expression of Bax and Bcl-2 in the lung. To determine which apoptotic pathways were induced by D. candidum, the mice were treated with 200 and $400 \mathrm{mg} / \mathrm{kg}$ b.w. dose, and the lung tissues were dissected and analyzed for apoptosis-related gene expression by RT-PCR and western blotting. As shown in Fig. 2, in the presence of $D$. candidum, there were significant differences $(\mathrm{P}<0.05)$ in the expression of $\mathrm{Bax}$ and $\mathrm{Bcl}-2$, with an increase in Bax expression and a reduction in Bcl-2 expression, as determined by RT-PCR. The Bax gene expression increased with $D$. candidium treatment, in a dose dependent manner, and $\mathrm{Bcl}-2$ gene expression showed a crosscurrent when mice were treated with $D$. candidium $(\mathrm{P}<0.05)$. The results suggested that $D$. candidum induced apoptosis in 26-M3.1 cell-injected lung metastatic mice through a Bax- and Bcl-2-dependent pathway. The increased expression of Bax and decreased expression of Bcl-2 induced by $400 \mathrm{mg} / \mathrm{kg} \mathrm{D}$. candidum was more notable at the mRNA expression level, as compared with the $200 \mathrm{mg} / \mathrm{kg}$ dose. From these results, $D$. candidum showed good anticancer effects in its ability to induce apoptosis, and these effects were observed in a dose-dependent manner.

Metastasis-related gene expression of MMPs and TIMPs in the lung. RT-PCR and western blot analysis was conducted to investigate whether the inhibitory effects of $D$. candidum on metastasis were due to gene regulation of metastatic mediators, such as MMPs (MMP-2 and MMP-9) and TIMPs (TIMP-1 and TIMP-2). The expression of MMPs and TIMPs was therefore analyzed in lung tissues taken from control and D. candidum-treated mice. As shown in Fig. 3, D. candidum significantly decreased the mRNA and protein expression of MMP-2 and MMP-9 $(\mathrm{P}<0.05)$, and significantly increased the expression of TIMP-1 and TIMP-2 $(\mathrm{P}<0.05)$. The most prominent anti-metastatic effects were associated with the most marked decrease in expression of MMP-2 and MMP-9, together with the most marked increase in expression of TIMP-1 and TIMP-2. These results suggested that the higher $400 \mathrm{mg} / \mathrm{kg}$ dose of $D$. candidum, cultivated in the presence of sulfur, could elicit a stronger anti-metastatic activity as compared with the lower $200 \mathrm{mg} / \mathrm{kg}$ dose.

Content of the D. candidum leaf. Eleven compounds were isolated and identified from the D. candidum leaf. Compound 1 was obtained as a clear crystal, and the ${ }^{1} \mathrm{H}-\mathrm{NMR}$ spectrum of this compound was as follows: $\delta 6.92(2 \mathrm{H}, \mathrm{d}), 6.62(2 \mathrm{H}, \mathrm{d}), 6.06$ $(2 \mathrm{H}, \mathrm{s}), 6.03(1 \mathrm{H}, \mathrm{s}), 2.65(4 \mathrm{H}, \mathrm{m})$. This compound was confirmed as dihydrogen resveratrol. Compound 2 was obtained as a white powder, and the $1 \mathrm{H}-\mathrm{NMR}$ spectrum of this compound was as follows: $\delta 6.98(2 \mathrm{H}, \mathrm{d}), 6.74(2 \mathrm{H}, \mathrm{d}), 6.62(1 \mathrm{H}, \mathrm{s}), 6.47(1 \mathrm{H}, \mathrm{d})$, $4.83(1 \mathrm{H}, \mathrm{d}), 4.63(1 \mathrm{H}, \mathrm{d}), 3.1-3.8(12 \mathrm{H}), 3.73(3 \mathrm{H}, \mathrm{s}), 3.69(3 \mathrm{H}, \mathrm{s})$, $2.74(4 \mathrm{H}, \mathrm{m})$. This compound was confirmed as dendromoniliside E. Compound 3 was obtained as a black red needle, and the ${ }^{1} \mathrm{H}-\mathrm{NMR}$ spectrum of this compound was as follows: $\delta 11.00$ $(1 \mathrm{H}, \mathrm{s}), 8.15(1 \mathrm{H}, \mathrm{d}), 6.06(2 \mathrm{H}, \mathrm{s}), 8.07(1 \mathrm{H}, \mathrm{d}), 6.95(1 \mathrm{H}, \mathrm{s}), 6.83$ $(1 \mathrm{H}, \mathrm{s}), 6.15(1 \mathrm{H}, \mathrm{s}), 3.96(3 \mathrm{H}, \mathrm{s}), 3.93(3 \mathrm{H}, \mathrm{s})$. This compound was confirmed as denbinobin. Compound 4 was obtained as a colorless needle, and the ${ }^{1} \mathrm{H}-\mathrm{NMR}$ spectrum of this compound was as follows: $\delta 4.72(2 \mathrm{H}, \mathrm{m}), 3.85(1 \mathrm{H}, \mathrm{d}), 6.06(2 \mathrm{H}, \mathrm{s}), 2.53(1 \mathrm{H}$, d), $2.49(1 \mathrm{H}, \mathrm{t}), 2.39(1 \mathrm{H}, \mathrm{dd}), 2.21(1 \mathrm{H}, \mathrm{dd}), 1.64(1 \mathrm{H}, \mathrm{m}), 1.35$ $(3 \mathrm{H}, \mathrm{s}), 1.03(3 \mathrm{H}, \mathrm{d}), 0.95(3 \mathrm{H}, \mathrm{d})$. This compound was confirmed 
Table II. Serum IL-6, IL-12, TNF- $\alpha$, and IFN- $\gamma$ levels of mice bearing 26-M3.1 cells treated with D. candidum.

\begin{tabular}{lcccc}
\hline Treatment & IL-6 & IL-12 & TNF- $\alpha$ & IFN- $\gamma$ \\
\hline Control (untreated) & $235.7 \pm 33.8^{\mathrm{a}}$ & $712.1 \pm 55.8^{\mathrm{a}}$ & $84.1 \pm 12.0^{\mathrm{a}}$ & \\
$\begin{array}{l}\text { D. candidum }(\mathrm{mg} / \mathrm{kg}) \\
\end{array}$ & $172.7 \pm 21.6^{\mathrm{b}}$ & $571.7 \pm 42.9^{\mathrm{b}}$ & & \\
200 & $113.0 \pm 26.1^{\mathrm{c}}$ & $338.6 \pm 39.7^{\mathrm{c}}$ & $61.2 \pm 4.9^{\mathrm{b}}$ & \\
400 & $11.7^{\mathrm{a}}$ & $50.6 \pm 6.6^{\mathrm{c}}$ & \\
\hline
\end{tabular}

${ }^{\mathrm{a}-\mathrm{c}}$ Mean values with different letters in the same column are significantly different $(\mathrm{P}<0.05)$ according to Duncan's multiple range test. $D$. candidum, Dendrobium candidum.

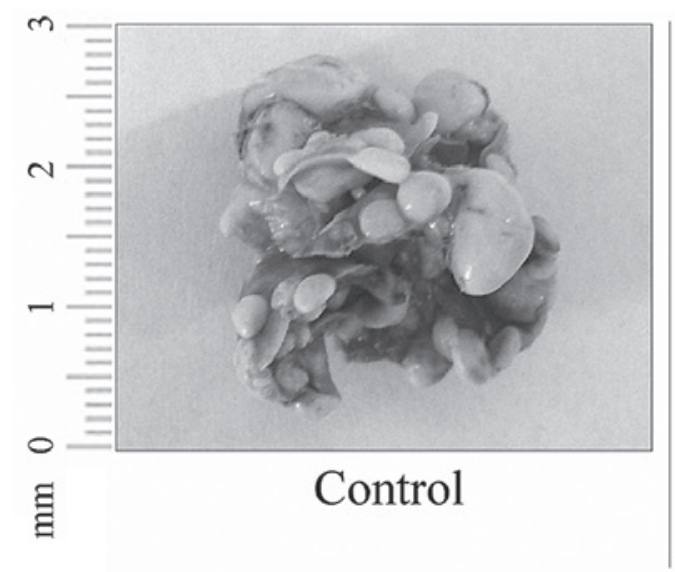

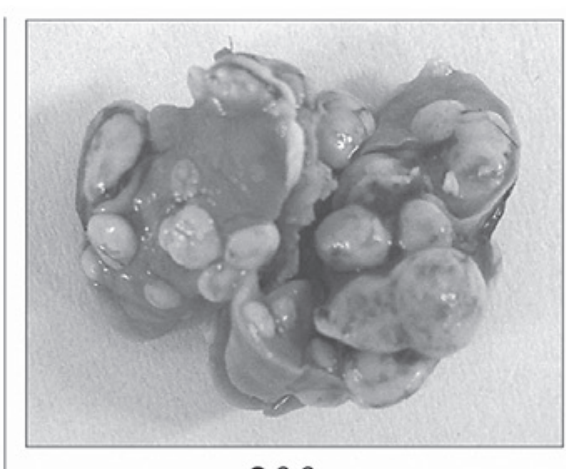

200

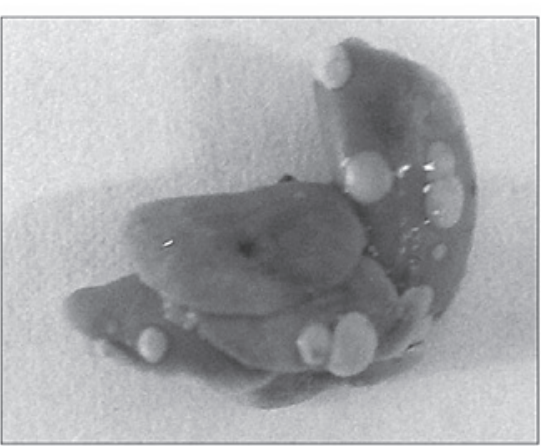

400

D. candidum aqueous extract (mg/kg b.w. dose)

Figure 1. Inhibitory effects of different concentrations of Dendrobium candidum aqueous extract on the metastasis of tumors produced by colon 26-M3.1 cells in Balb/c mice.
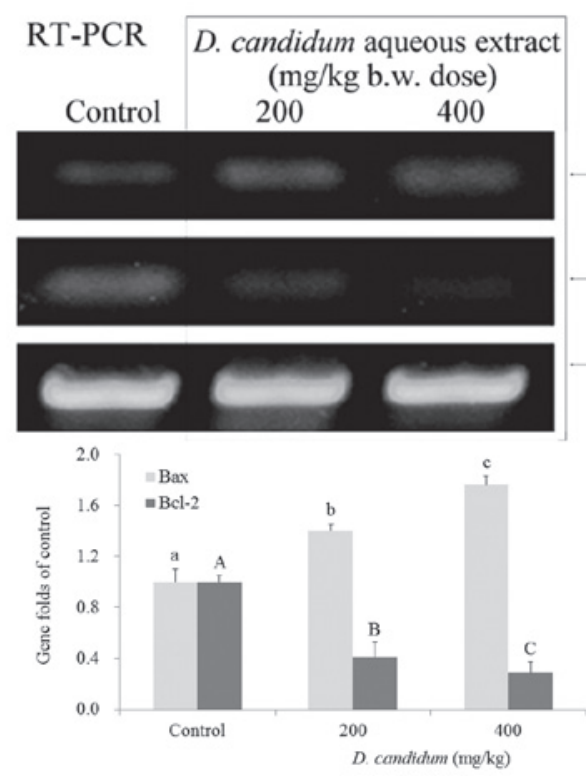

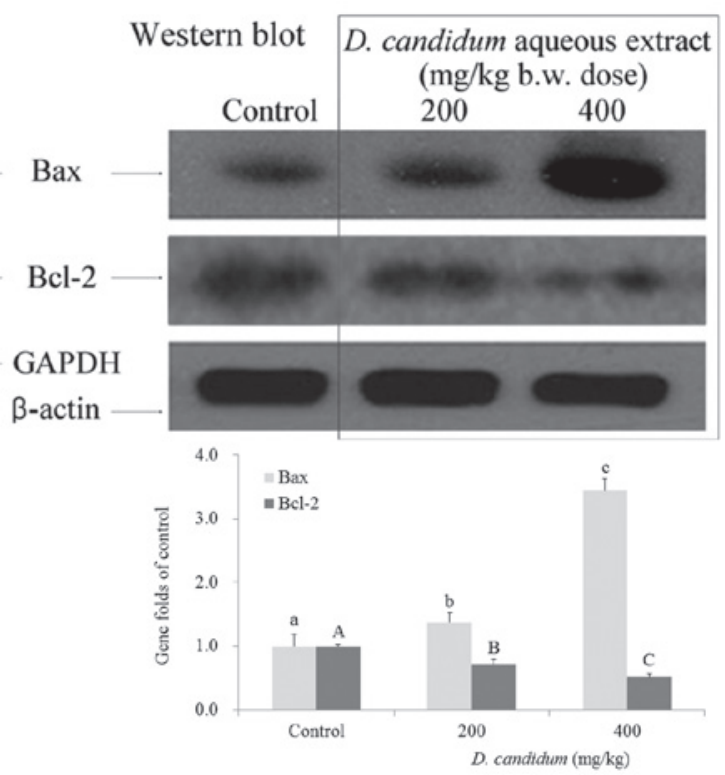

Figure 2. Effects of aqueous extract from D. candidum on the mRNA (left) and protein (right) expression of Bax and Bcl-2 in mice. Fold ratio = gene expression/GAPDH x control numerical value (control fold ratio: 1$)$. ${ }^{\mathrm{a}-\mathrm{c}, \mathrm{A}-\mathrm{C}}$ Mean values with different letters over the bars are significantly different $(\mathrm{P}<0.05)$ according to Duncan's multiple-range test. ${ }^{\mathrm{a}, \mathrm{A}} \mathrm{P}<0.05$, vs. the control; ${ }^{\mathrm{b}, \mathrm{B}} \mathrm{P}<0.05$, vs. the $200 \mathrm{mg} / \mathrm{kg}$ D. candidum dose; ${ }^{\mathrm{c}, \mathrm{C}} \mathrm{P}<0.05$, vs. the $400 \mathrm{mg} / \mathrm{kg} D$. candidum dose. D. candidum, Dendrobium candidum; RT-PCR, quantitative polymerase chain reaction.

as aduncin. Compound 5 was obtained as a white needle, and the ${ }^{1} \mathrm{H}-\mathrm{NMR}$ spectrum of this compound was as follows: $\delta 8.25$ $(1 \mathrm{H}, \mathrm{s}), 8.10(1 \mathrm{H}, \mathrm{s}), 5.90(1 \mathrm{H}, \mathrm{d}), 4.66(1 \mathrm{H}, \mathrm{dd}), 3.5-4.2(4 \mathrm{H}$, $\mathrm{m})$. This compound was confirmed as adenosine. Compound 6 was obtained as a white powder, and the ${ }^{1} \mathrm{H}-\mathrm{NMR}$ spectrum of this compound was as follows: $\delta 7.95(1 \mathrm{H}, \mathrm{d}), 5.85(1 \mathrm{H}, \mathrm{d})$, 


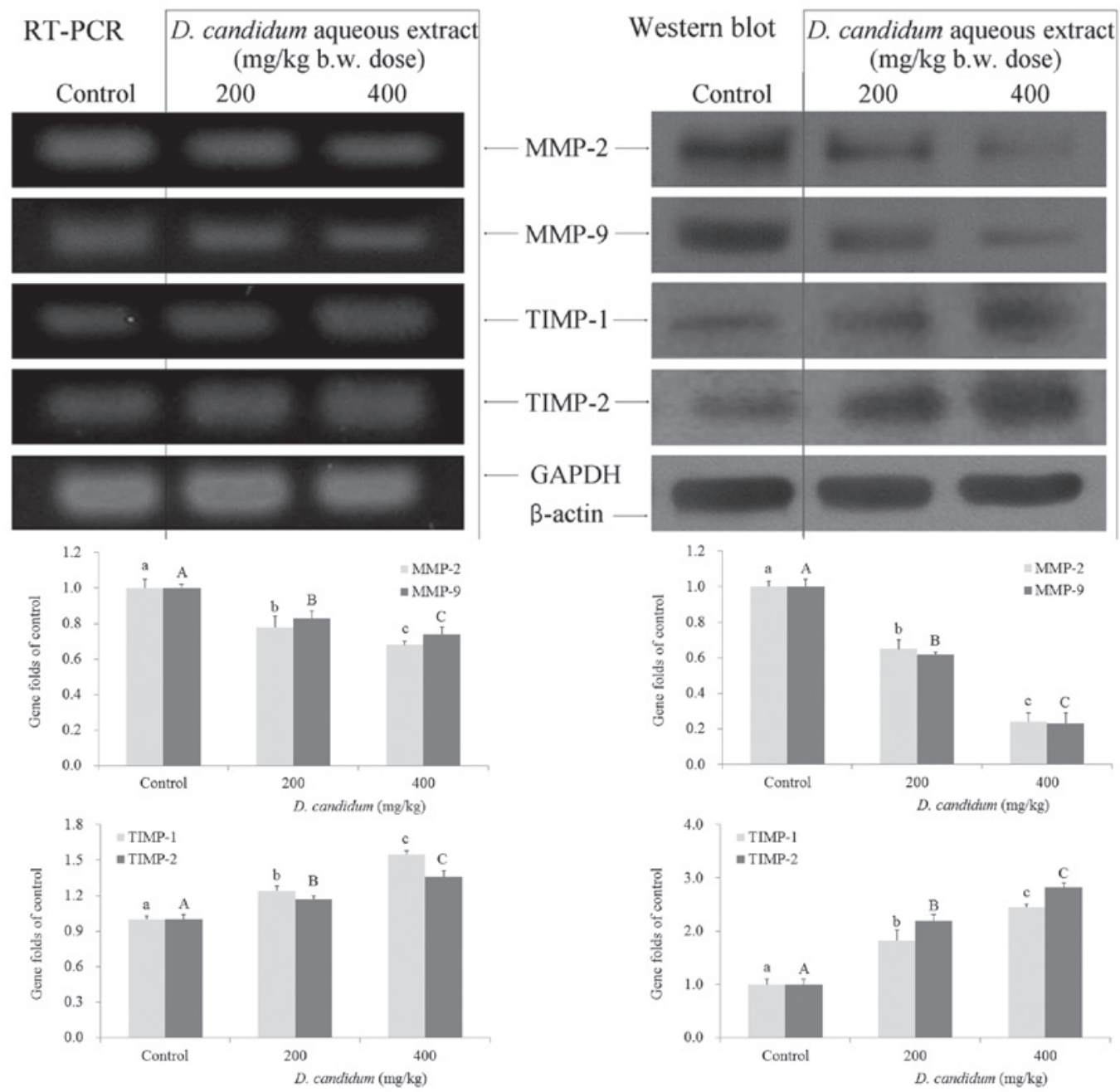

Figure 3. Effects of aqueous extract from $D$. candidum on the mRNA (left) and protein (right) expression of MMPs and TIMPs in mice. Fold ratio $=$ gene expression/GAPDH $x$ control numerical value (control fold ratio: 1 ). ${ }^{\text {a-c, } A-\mathrm{C}}$ Mean values with different letters over the bars are significantly different $(\mathrm{P}<0.05)$ according to Duncan's multiple-range test. ${ }^{\mathrm{a}, \mathrm{A}} \mathrm{P}<0.05$, vs. the control; ${ }^{\mathrm{b}, \mathrm{B}} \mathrm{P}<0.05$, vs. the $200 \mathrm{mg} / \mathrm{kg}$ D. candidum dose; ${ }^{\mathrm{c}, \mathrm{C}} \mathrm{P}<0.05$, vs. the $400 \mathrm{mg} / \mathrm{kg}$ D. candidum dose. D. candidum, Dendrobium candidum; MMP, matrix metalloproteinase; TIMP, tissue inhibitor of matrix metalloproteinases; RT-PCR, quantitative polymerase chain reaction.

$5.66(1 \mathrm{H}, \mathrm{d}), 3.2-4.3(5 \mathrm{H}, \mathrm{m})$. This compound was confirmed as uridine. Compound 7 was obtained as a clear crystal, and the ${ }^{1} \mathrm{H}$-NMR spectrum of this compound was as follows: $\delta 10.60$ $(1 \mathrm{H}, \mathrm{s}), 7.92(1 \mathrm{H}, \mathrm{s}), 6.45(2 \mathrm{H}, \mathrm{s}), 5.66(1 \mathrm{H}, \mathrm{d}), 3.4-4.4(5 \mathrm{H}, \mathrm{m})$. This compound was confirmed as guanosine. Compound 8 was obtained as a white powder, and the ${ }^{1} \mathrm{H}-\mathrm{NMR}$ spectrum of this compound was as follows: $\delta 7.65(1 \mathrm{H}, \mathrm{d}), 7.41(2 \mathrm{H}, \mathrm{d}), 6.85(2 \mathrm{H}$, d), $6.33(1 \mathrm{H}, \mathrm{d}), 4.17(2 \mathrm{H}, \mathrm{t}), 1.69(2 \mathrm{H}, \mathrm{m}), 1.25(54 \mathrm{H}, \mathrm{m}), 0.85$ $(3 \mathrm{H}, \mathrm{t})$. This compound was confirmed as defuscin. Compound 9 was obtained as a white powder, and the ${ }^{1} \mathrm{H}-\mathrm{NMR}$ spectrum of this compound was as follows: $\delta 7.45(2 \mathrm{H}, \mathrm{d}), 6.82(2 \mathrm{H}, \mathrm{d})$, $6.81(1 \mathrm{H}, \mathrm{d}), 5.83(1 \mathrm{H}, \mathrm{d}), 4.16(2 \mathrm{H}, \mathrm{t}), 1.67(2 \mathrm{H}, \mathrm{m}), 1.23(54 \mathrm{H}$, m), $0.88(3 \mathrm{H}, \mathrm{t})$. This compound was confirmed as $n$-triacontyl cis-p-coumarate. Compound 10 was obtained as a white powder, and the ${ }^{1} \mathrm{H}-\mathrm{NMR}$ spectrum of this compound was as follows:

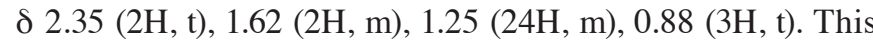
compound was confirmed as hexadecanoic acid. Compound 11 was obtained as a white powder, and the ${ }^{1} \mathrm{H}-\mathrm{NMR}$ spectrum of this compound was as follows: $\delta 3.85(2 \mathrm{H}, \mathrm{t}), 1.75(2 \mathrm{H}, \mathrm{m})$, $1.45(2 \mathrm{H}, \mathrm{m}), 1.22(54 \mathrm{H}, \mathrm{m}), 0.85(3 \mathrm{H}, \mathrm{t})$. This compound was confirmed as hentriacontane.

\section{Discussion}

Although D. candidum has been used as a traditional Chinese medicine, there has been little scientific research regarding its mechanism of action. D. candidum contains high concentrations of benzenes and their derivatives, phenolic, lignans, lactone, flavonoids and 18 novel D. candidum pigments (14). D. candidum has been previously reported to have various therapeutic effects on numerous pathological conditions, including inflammation, immunity, hyperglycemia and cancer (15).

Lower levels of IL-6, IL-12, IFN- $\gamma$ and TNF- $\alpha$ cytokines are indicative of improved anticancer effects $(16,17)$. IL-6 is regarded as an important tumor-promoting factor in various types of human cancer. An increased expression of IL-6 has been found in patients with cancer, in serum and tumor tissue (18). IL-12 has been shown to contribute to tumor eradication, through IFN- $\gamma$-dependent induction of the anti-angiogenic factors interferon-inducible protein 10 and monokine induced by gamma interferon (19). In addition, a previous study has shown that drugs targeting TNF- $\alpha$ may be 
useful for the treatment of cancers (13). In the present study, it was observed that the levels of IL-6, IL-12, TNF- $\alpha$ and IFN- $\gamma$ in mice injected with 26-M3.1 cells were markedly decreased following $D$. candidum treatment. Based on this study, D. candidum showed a strong preventive effect on the development of lung metastases.

Tumor cells are able to migrate to another site, penetrate the vessel walls, continue to multiply and eventually form another tumor. Colon 26-M3.1 carcinoma cells have been previously used to evaluate anti-metastatic effects in vivo (20). Based on in vivo data from previous studies, 26-M3.1 colon carcinoma cells were used to examine the effects of $D$. candidum on metastasis in mice. The results further proved the activity of D. candidum, and the observed anticancer effects occurred in a dose-dependent manner.

Apoptosis is a fundamental cell event, and understanding its mechanisms of action will have a significant effect on antitumor therapy. The Bcl-2 family, which includes promoters (Bax and Bid) and inhibitors (Bcl-2 and Bcl-xL), is a key regulator in mitochondria-mediated apoptosis (21). In the present study, the gene and protein expression of Bax was increased, whereas the protein expression of $\mathrm{Bcl}-2$ was decreased following treatment with $D$. candidum. Based on the gene expression results, D. candidum showed strong activity in promoting apoptosis in cancer.

MMPs comprise a family of zinc-dependent endopeptidases that function in tumorigenesis and metastasis (22). MMPs can cleave the majority of all extracellular matrix (ECM) substrates. Degradation of the ECM is a key event in tumor progression, invasion and metastasis (23). Among the MMP family members, MMP-2 and MMP-9 are molecules important for cancer invasion, and have been shown to be highly expressed in cancer cells (24). Inhibition of MMP activity is useful for controlling tumorigenesis and metastasis (25). TIMPs are naturally occurring inhibitors of MMPs that prevent catalytic activity by binding to activated MMPs, thereby blocking the degradation of the ECM. Disturbances in the ratio between MMPs and TIMPs have been observed during tumorigenesis (26). Maintaining the balance between MMPs and TIMPs, or increasing TIMP activity, are useful methods by which to control tumor metastasis (27). In the present study, strong anti-metastatic effects were correlated with a reduction of MMPs and an increase of TIMPs following administration of $D$. candidum in mice. From the results, $D$. candidum showed a strong anti-metastatic effect and, therefore, may be a functional drug for cancer prevention.

Numerous compounds were isolated and identified by NMR of the D. candidum leaf in the present study. Resveratrol is an antioxidant that has been often recommended for use as treatment in patients with colon cancer (28). Denbinobin is a biologically active chemical that has been demonstrated to inhibit colon cancer growth both in vitro and in vivo (29). Aduncin is a unique component that has only been found in Dendrobium. Aduncin may have anticancer effects, but its function requires further research (30). Adenosine serves as a physiological regulator and acts as a cardio-, neuro- and chemo-protector, and as an immunomodulator. Adenosine has been shown to exert anticancer effects at certain concentration. When administered in combination with chemotherapy, adenosine can enhance the chemotherapeutic index and acts as a chemoprotective agent (31). The availability of uridine can alter the sensitivity of tumor cells to antimetabolites. Adenine is incorporated into polynucleotides and the two compounds have been identified as important cancer-associated substances (32). Defuscin, $n$-triacontyl cis-p-coumarate, hexadecanoic acid and hentriacontane have also shown functional activities in human health $(33,34)$. Taken together, these compounds all exhibit anticancer activities, and with the high content of functional compounds, this may explain why $D$. candidum showed a functional effect in cancer prevention. The synergy of these bioactive components may increase the anticancer effects of D. candidum.

In summary, the present study found that D. candidum has potent in vivo anti-metastatic activity, particularly in the inhibition of in vivo tumor metastasis. The analysis of cytokine levels, as well as mRNA and protein expression, has provided a mechanistic basis for these functional effects and a scientific basis for the development of D. candidum in cancer therapy.

\section{Acknowledgements}

The present study was supported by the Program for Innovation Team Building at Institutions of Higher Education in Chongqing (grant no. KJTD201325).

\section{References}

1. Jones WE, Kuehnle AR and Arumuganathan K: Nuclear DNA content of 26 orchids (Orchidaceae) genera with emphasis on Dendrobium. Ann Bot 82: 189-194, 1998.

2. Wang Q, Sun P, Li G, Zhu K, Wang C and Zhao X: Inhibitory effects of Dendrobium candidum Wall ex Lindl. on azoxymethane- and dextran sulfate sodium-induced colon carcinogenesis in C57BL/6 mice. Oncol Lett 7: 493-498, 2014.

3. Xiao F and Zhang JZ: First report of Fusarium oxysporum causing wilt of Dendrobium candidum in Zhejiang province, China. Plant Dis 96: 1377, 2012.

4. Shao H, Zhang LQ, Li JM and Wei RC: Advances in research of Dendrobium officinale. Chinese Tradit Herbal Drugs 35: 109-111, 2004.

5. Chiang AC and Massagué J: Molecular basis of metastasis. N Engl JMed 359: 2814-2823, 2008 .

6. Bjerkvig R, Tysnes BB, Aboody KS, Najbauer J and Terzis AJ: Opinion: the origin of the cancer stem cell: current controversies and new insights. Nat Rev Cancer 5: 899-904, 2005.

7. Zetter BR: Angiogenesis and tumor metastasis. Annu Rev Med 49: 407-424, 1998 .

8. Itoh Y and Nagase H: Matrix metalloproteinases in cancer. Essays Biochem 38: 21-36, 2002.

9. Brew K, Dinakarpandian D and Nagase H: Tissue inhibitors ofmetalloproteinases: evolution, structure and function. Biochim Biophys Acta 1477: 267-283, 2000.

10. Chambers AF, Groom AC and MacDonald IC: Dissemination and growth of cancer cells in metastatic sites. Nat Rev Cancer 2: $563-572,2002$

11. Zhao X, Wang Q, Qian Y and Song JL: Ilex kudingcha C.J. Tseng (Kudingcha) has in vitro anticancer activities in MCF-7 human breast adenocarcinoma cells and exerts anti-metastatic effects in vivo. Oncol Lett 5: 1744-1748, 2013.

12. Zhao X, Kim SY and Park KY: Bamboo salt has in vitro anticancer activity in HCT-116 cells and exerts anti-metastatic effects in vivo. J Med Food 16: 9-19, 2013

13. Chen LH, Song JL, Qian Y, Zhao X, Suo HY and Li J: Increased preventive effect on colon carcinogenesis by use of resistant starch (RS3) as the carrier for polysaccharide of Larimichthys crocea swimming bladder. Int J Mol Sci 15: 817-829, 2014.

14. Li Y, Wang CL, Wang FF, Dong HL, Guo SX, Yang JS and Xiao PG: Chemical constituents of Dendrobium candidum. China J Chin Mater Med 13: 1715-1719, 2010.

15. Shao H, Zhang LQ, Li JM and Wei RC: Inhibitory effects of water extracts from four species of Dendrobiums on HelaS3 cells and HepG2 cells. J Anhui Agri Sci 36: 15968-15970, 2008. 
16. Lin WW and Karin M: A cytokine-mediated link between innate immunity, inflammation, and cancer. J Clin Invest 117: 1175-1183, 2007.

17. Cahlin C, Körner A, Axelsson H, Wang WH, Lundholm K and Svanberg E: Experimental cancer cachexia: the role of host-derived cytokines interleukin (IL)-6, IL-12, interferon-gamma, and tumor necrosis factor alpha evaluated in gene knockout, tumor-bearing mice on C57 Bl background and eicosanoid-dependent cachexia. Cancer Res 60: 5488-5493, 2000.

18. Kishimoto T, Akira S and Taga T: Interleukin- 6 and its receptor: a paradigm for cytokines. Science 258: 593-597, 1992.

19. Engel MA and Neurath MF: Anticancer properties of the IL-12 family - focus on colorectal cancer. Curr Med Chem 17: 3303-3308, 2010.

20. Ha ES, Hwang SH, Shin KS, Yu KW, Lee KH, Choi JS Park WM and Yoon TJ: Anti-metastatic activity of glycoprotein fractionated from Acanthopanax senticosus, involvement of NK-cell and macrophage activation. Arch Pharm Res 27 217-224, 2004

21. Zhao X, Song JL, Kim JD, Lee JS and Park KY: Fermented $\mathrm{Pu}$-erh tea increases in vitro anticancer activities in HT-29 cells and has antiangiogenetic effects on HUVECs. J Environ Pathol Toxicol Oncol 32: 275-288, 2013.

22. Sreenath T, Matrisian LM, Stetler-Stevenson W, Gattoni-Celli S and Pozzatti RO: Expression of matrix metalloproteinase genes in transformed rat cell lines of high and low metastatic potential. Cancer Res 52: 4942-4947, 1992.

23. Chaudhary AK, Singh M, Bharti AC, Asotra K, Sundaram S and Mehrotra R: Genetic polymorphisms of matrix metalloproteinases and their inhibitors in potentially malignant and malignant lesions of the head and neck. J Biomed Sci 17: 10, 2010.

24. Zucker S and Vacirca J: Role of matrix metalloproteinases (MMPs) in colorectal cancer. Cancer Metastasis Rev 23: 101-117, 2004.
25. Duffy MJ and McCarthy K: Matrix metalloproteinases in cancer: prognostic markers and targets for therapy (review). Int J Oncol 12: 1343-1348, 1998.

26. Okazaki I, Noro T, Tsutsui N, Yamanouchi E, Kuroda H, Nakano M, Yokomori H and Inagaki Y: Fibrogenesis and carcinogenesis in nonalcoholic steatohepatitis (NASH): involvement of matrix metalloproteinases (MMPs) and tissue inhibitors of metalloproteinase (TIMPs). Cancers (Basel) 6: 1220-1255, 2014

27. Mysliwiec AG and Ornstein DL: Matrix metalloproteinases in colorectal cancer. Clin Colorectal Cancer 1: 208-219, 2002.

28. Aggarwal BB, Bhardwaj A, Aggarwal RS, Seeram NP, Shishodia S and Takada Y: Role of resveratrol in prevention and therapy of cancer: preclinical and clinical studies. Anticancer Res 24: 2783-2840, 2004.

29. Yang KC, Uen YH, Suk FM, Liang YC, Wang YJ, Ho YS, Li IH and Lin SY: Molecular mechanisms of denbinobin-induced anti-tumorigenesis effect in colon cancer cells. World J Gastroenterol 11: 3040-3045, 2005.

30. Ng TB, Liu J, Wong JH, Ye X, Wing Sze SC, Tong Y and Zhang KY: Review of research on Dendrobium, a prized folk medicine. Appl Microbiol Biotechnol 93: 1795-1803, 2002.

31. Ohana G, Bar-Yehuda S, Barer F and Fishman P: Differential effect of adenosine on tumor and normal cell growth: focus on the A3 adenosine receptor. J Cell Physiol 186: 19-23, 2001.

32. Graff S, Engelman M, Gillespie HB and Graff AM. Guanine in cancer. Cancer Res 11: 388-392, 1951.

33. Benoit SC, Kemp CJ, Elias CF, et al: Palmitic acid mediates hypothalamic insulin resistance by altering PKC-theta subcellular localization in rodents. J Clin Invest 119: 2577-2589, 2009.

34. Liang Q, Liang ZS, Wang JR and Xu WH: Essential oil composition of Salvia miltiorrhiza flower. Food Chem 113: 592-594, 2009. 